\title{
The HPV Vaccine - A Necessary Weapon in the Fight against Cancers
}

The Editor,

Sir,

The burden of Human Papilloma Virus (HPV) in Latin American and the Caribbean must be underscored as the region has recorded some of the highest rates (1), reporting $80 \%$ of the cervical cancers in the world (2). With a population of over 1 million women ages 15 years and older at risk of developing HPV (3), Jamaica boasts a world leading prevalence rate of 54\% (4), $35 \%$ of which is oncogenic (5), the highest incidence being among the younger age groups. HPV is also responsible for oral, vuval, vaginal and anal cancers in women and penile oral and anal cancers in men.

The use of the Human Papillomavirus (HPV) vaccination as a primary prevention strategy is an important factor in the fight against this virus among the population. With the national focus being on primary prevention, there has been strong advocacy from medical and other interested personnel for the inclusion of the HPV in the national vaccine programme. Over 50 countries worldwide has since included HPV vaccine in their national immunization programme with only Trinidad and Tobago representing the Caribbean. Despite the vaccine being available in over 80 countries worldwide and some contemplating the inclusion of boys in their vaccine cohort, it is not yet available in Jamaica and other vulnerable Caribbean nations such as Haiti, who has recorded a high mortality rate of 48.1 per 100,000 . 
The recommendation for the immunization of adolescent girls with the HPV vaccine before exposure to the virus will result in reduced incidence of cervical cancer (1) and other HPV causing cancers. It is agreed that the benefits of the HPV vaccine are significant though the cost is prohibitive and the average Jamaican who is most likely at the highest risk may not be able to afford this life saving drug. For developing countries like Jamaica, the affordability also depends on the proposed cohort to be vaccinated. With no HPV programme in place, the Government of Jamaica should make every effort to introduce this vaccine in the Expanded Programme of Immunization (EPI) in Jamaica. This will be a welcomed addition to the current fight against vaccine preventable diseases. However, the inclusion of boys into the cohort will have to be taken after its' introduction to girls and after much consultation. Studies have identifies the benefits of herd immunity if a minimum of 50\% of females are vaccinated (6). With Jamaica's history of exceptional vaccine coverage of over $90 \%$ for most vaccines a $50 \%$ coverage in HPV is achievable. In the interim, improved screening programmes will aid in the identification of pockets of vulnerability and classification of target groups. Additionally, the introduction of the vaccine to all females will eventually result in herd immunity that will essentially provide protection for our boys and men.

Keywords: Vaccine, cervical cancer, cohort

\section{S Chisholm-Ford}

From: The UWI School of Nursing, The University of the West Indies, Mona, Kingston, Jamaica.

Correspondence: Mrs S Chisholm-Ford, The UWI School of Nursing, 9 Gibraltar Camp Way Kingston 6. E-mail: Sandra.chisholmford02@uwimona.edu.jm 


\section{REFERENCES}

1. Villa, LL. (2012). Cancer in Latin America and the Caribbean: The Problem and the Way to Solutions, Cancer Epidemiology Biomarkers and Prevention 21; 1409. doi: 10.1158/1055-9965.EPI-12-0147

2. Cutts, FT., Franceschi, S., Goldie, S., Castellsague, X., de Sanjose, S., Garnett, G. et al (2007). Human papillomavirus and HPV vaccines: a review. [Internet], [cited 2016, July 18] Available from: http://www.ncbi.nlm.nih.gov/pubmed/18026629

3. ICO Information Centre on HPV and Cancer (2016). Human Papillomavirus and Related Cancers, Fact Sheet 2016. [Internet], [cited 2016, July 18] Available from: http://www.hpvcentre.net/statistics/reports/JAM_FS.pdf

4. Lewis-Bell K, Luciani S, Unger ER, Hariri S, McFarlane S, Steinau M. et al. Genital human papillomaviruses among women of reproductive age in Jamaica. [Internet], [cited 2016, July18] Available from: http://www.ncbi.nlm.nih.gov/pubmed/23698134. 2013.

5. PAHO. Situational analysis of cervical cancer prevention and control in the Caribbean. [Internet], [cited 2016, July 18] Available from: http://www.paho.org/hq/index.php?option=com_docman\&task=doc_view\&gid=23829\&I temid 2013.

6. Canfell K, Chesson H, Kulasingam SL, Berkhof J, Diaz M, Kim, JJ. Modeling Preventative Strategies against HPV-Related Disease in Developed Countries. Pub Med Central; 30 (05). doi: 10.1016/j.vaccine.2012.06.091 